\title{
Experiências urbanas e tensões: trajetória, oralidade e música em Bezerra da Silva
}

\author{
Maria Izilda Santos de Matos* \\ Eder Aparecido Ferreira Sedano*
}

Bezerra da Silva hoje é o rei da cocada preta; seus últimos quatro ou cinco LPs, recheados de condimentados sambandidos, venderam sempre de cem a duzentas mil cópias, com títulos explícitos como É esse aí que é o homem, Produto do Morro, Malandro Rife e Descendo a Colina Maldita.

(Souza, 1986).

Como destacado acima, Bezerra da Silva ficou conhecido como intérprete do chamado sambandido; questionando essa denominação, ele dizia ser "Embaixador do samba e dos morros cariocas". Privilegiando a trajetória artística e a obra de Bezerra da Silva, este artigo se propóe a discutir as questóes referentes a experiências urbanas nos morros cariocas. Tendo como base a metodologia da

* Professora Titular da Pontifícia Universidade Católica de São Paulo (PUC/SP), Livre docente (PUC/ SP, 2017), Pesquisadora 1A do Conselho Nacional de Desenvolvimento Científico e Tecnológico (CNPQ). E-mail: mismatos@pucsp.br.

** Doutorando do PPG de História da PUC/SP, bolsista da Coordenação de Aperfeiçoamento de Pessoal de Nível Superior (CAPES). E-mail: ederapfer@hotmail.com. 
História Oral (entrevistas elaboradas por outros pesquisadores e pelos autores), ${ }^{1}$ história e música (oralidade da poética das canções). ${ }^{2}$

\section{Bezerra da Silva: trajetória e memória}

José Bezerra da Silva nasceu em Recife (PE) no ano de 1927, filho de um marinheiro e da bordadeira Hercília, que, sozinha, criou o filho. Frente às dificuldades cotidianas, ainda criança, Bezerra começou a trabalhar, executando pequenos serviços. No mesmo período, desde então desenvolveu o gosto pela música. Como outros tantos nordestinos, decidiu migrar para o Rio de Janeiro, fazendo o trajeto como clandestino num navio, aos 15 anos de idade. Ao chegar na cidade, ele procurou pelo pai, que tinha constituído nova família, e, infelizmente, não o acolheu. Sozinho e sem ter aonde ficar, se empregou na construção civil.

Fui trabalhar na construção civil... eu disse: "Olha, eu não tenho onde morar, não tenho o que comer, não tenho nada, o senhor deixa eu dormir aí?" Ele disse: "Pode dormir na obra, e o pagamento é no sábado. Tem um rapaz aí que dá pensão, café, almoço, janta”. (A Cara..., 2000).

Depois, então eu fui morar no morro, subi no morro do Cantagalo e lá eu acabei de me criar. Quer dizer, vi tudo, aprendi tudo, aliás, o tempo não foi perdido né, eu consegui um diploma da universidade do mundo, que é muito difícil, poucos alunos passam nele, porque na universidade

1 Sobre o uso de depoimentos coletados por outros pesquisadores, lembra-se que "são incontáveis os exemplos disso na constituição de biografias de personagens, de movimentos musicais, ou ainda de gerações [...] As entrevistas também mostrarão perspectivas múltiplas, que tocarão não apenas a dimensão psicológica, mas também as dimensôes históricas ... e a psicossocial..." (Santhiago, 2013. p. 158). Os depoimentos e entrevistas de Bezerra da Silva localizados na trajetória da pesquisa foram incorporados criticamente, atentando-se para o contexto da sua realização (quem fez, como fez e como foi veiculado) e sendo entendidos como narrativas de memória colhidas a posteriori, nas quais foram erigidas a percepção do artista acerca da sua trajetória de vida, de trabalho como músico, compositor e intérprete, sendo os relatos tomados como representaçóes construídas de si mesmo que sistematicamente repetem episódios elegendo momentos e ocorridos (Portelli, 1996).

2 A perspectiva analítica da "história e música" se diferencia da história da música, pois incorpora questôes e aspectos variados, como: o artista (trajetória, formação, obra e produçáo), os estilos/gêneros e movimentos musicais, as cançóes (poética musical, palavra cantada), as interpretaçóes e arranjos, os circuitos culturais, boêmios e de sociabilidade, o consumo, recepçáo e gosto musical, acrescidos dos equipamentos e formas de veiculação, além de vários outros elementos das diferentes experiências sonoras (Matos, 2018). 
no mundo, não tem aproximação né, por exemplo, se a nota máxima for cem ou dez, você tem que tirar cem em todas as matérias, não tem nove, vírgula, é na dura mesmo. Então você aprende bem e vê a vida como ela é e fica tudo bem, fica tudo ótimo. (A Cara..., 2000).

Pela narrativa, observa-se que Bezerra tinha no morro do Cantagalo uma referência territorial e de redes de sociabilidade. Foi um dos seus vizinhos, Alcides Fernandes (compositor conhecido como Doca), que o convidou para trabalhar como instrumentista na orquestra da Rádio Clube do Brasil, no entanto, era uma atividade esporádica e sem renda fixa, por isso, precisava conciliá-la com a construção civil. Rememora ainda que

De 1954 a 1961 - sete anos né? Eu me desempreguei... Não tinha mais música, tudo me fugiu da mente. E eu fui... Bom, não sei o que aconteceu na minha vida, então eu fui para a sarjeta. Eu já fui mendigo na rua, andando pra baixo e para cima em Copacabana, sujo, sem ter onde dormir, sem ter o que comer. Ali foi um negócio que marcou muito a minha vida, me serviu como lição. (A Cara..., 2000).

Com tristeza, Bezerra narrou as dificuldades, bem como a ajuda e acolhimento obtidos com a conversão à Umbanda (foi iniciado e morou num terreiro por quatro anos). Em 1961 voltou a trabalhar e retomou sua carreira artística, atuando como instrumentista em gravaçóes e acompanhando artistas como Clementina de Jesus e Roberto Ribeiro.

Em 1965, sua composição "Nunca mais sambo", interpretada por Marlene, foi premiada no concurso de carnaval da Rádio Nacional. Nesse mesmo ano, Bezerra casou-se com Ilma (sua esposa por 22 anos, com quem teve seis filhos). Apesar do desejo de se dedicar exclusivamente à carreira musical, tinha compromissos com o sustento da família e, para tanto, buscava acumular os serviços de pintor de parede com a música. Aos poucos, conseguiu consolidar sua carreira artística, se destacando como instrumentista na orquestra do Canecão e participando de programas televisivos na Rede Globo, seu primeiro emprego com carteira assinada, entre 1977 e 1984 (VIANNA, 1999, p. 31). ${ }^{3}$

Seu primeiro disco gravado (de 1969) foi um compacto com as músicas: "Essa viola é testemunha" e "Mana cadê meu boi", pela Copacabana Discos. Já

3 Para exercer profissionalmente atividades musicais, era necessário o registro na Ordem dos Músicos do Brasil (OMB), obtido através de exame interno. Para tanto, Bezerra estudou violão clássico e vários outros instrumentos (cavaquinho, trompete, piano e percussão), ampliando, assim, seus conhecimentos musicais. 
o primeiro LP, "Bezerra da Silva o rei do coco, volume 1", foi lançado em 1975; no ano seguinte, gravou "Bezerra da Silva o rei do coco, volume 2" (ambos pela Tapecar).

A mudança de gênero musical (do coco para o samba de partido-alto) se deu a partir de 1978, quando gravou "Genaro e Bezerra da Silva: partido alto nota 10", pela CID. Na sequência, foram lançados os LP's "Partido alto nota 10 " volume 2 e volume 3, em parceria com outros sambistas (Genaro, Jorge Garcia, Ovídio Bessa e Rey Jordão). Em 1981, foi contratado pela RCA (depois BMG-Ariola, permanecendo até 1993). Neste período, lançou um LP por ano, atingindo grandes vendagens, alcançando o sucesso e reconhecimento sonhados. Gravou 28 álbuns, sem contar coletâneas e participações em obras de outros artistas, chegando a mais de 3 milhóes de discos vendidos, tendo sido premiado com 11 discos de ouro (acima de 100 mil cópias vendidas), três de platina (acima de 250 mil cópias vendidas) e um de platina duplo (acima de 500 mil cópias vendidas) (Morre..., 2005).

Apesar do sucesso, declarava-se decepcionado com o retorno financeiro, acusando as gravadoras e o Escritório Central de Arrecadação e Distribuição (ECAD) de desvio de valores:

O compositor, ele ganha duas vezes, então vamo lá, ele ganha execução e fonomecânico. A execução é quantas vezes toca a música por aí, rádio, show, aí o ECAD paga, e fonomecânico a gravadora paga. Só que ele é roubado na gravadora e é roubado no ECAD. Porque tem o dito popular "crioulo com muito dinheiro foge de casa", então tem que dar pouquinho que é pra poder... (Onde..., 2006).

Bezerra divulgava seu trabalho, nas rádios comunitárias e realizava shows nos morros e subúrbios. As temáticas de suas composições e interpretações priorizavam as experiências cotidianas dos moradores desses territórios.

Sou produto do morro

Por isso do morro não fujo e nem corro

Simbora gente!

No morro aprendi a ser gente

Nunca fui valente e sim conceituado

Em qualquer favela que eu chegar

Eu sou muito bem chegado

E no Canta Galo, na linha de frente

Naquele ambiente sou considerado 
Ih!

Sou produto do morro

Por isso do morro não fujo e nem corro

E eu também!

Eu sou produto do morro

Sem pedir socorro pra ninguém

Embarquei do asfalto na cruel sociedade

Que esconde os valores que no morro tem

Tenho pouco estudo, não fiz faculdade

E atestado de burro não assino também

Ih!

É que a música é meu alento

E o meu talento a Deus agradecer

E nesse momento é a Ele que peço

Se eu sou sucesso fiz por merecer

Sou favelado, mas tenho muita dignidade

E muita honestidade pra dar e vender, Ih!

(Produto do Morro) $^{4}$

Na canção "Produto do Morro" (1983), o personagem (compositor e intérprete) destaca que no morro aprendeu "a ser gente" (a viver em coletividade e respeitar as normas) e que em qualquer favela seria bem acolhido e reconhecido como igual, afirma ser "favelado" com muita "dignidade" e ter honestidade "pra dar e vender". A canção assinala os embates entre "o asfalto e o morro", enfatizando a crítica aos estereótipos impostos aos moradores dos morros.

Desta forma, observa-se que a intenção do intérprete era se identificar como "produto do morro" (nordestino, migrante, morador da favela), sedimentando a constituição de sua persona artística o "Embaixador do samba e dos morros". Apesar de não ser de sua autoria, a interpretação de Bezerra tornou-se uma recomposição, sendo possível observar suas interferências, entre outras, através da introdução de expressóes como "Simbora Gente" e "E eu também".

Bezerra da Silva foi considerado como um herdeiro dos chamados "sam-

4 Compositores: Eliezer da Ponte e Walter Coragem. LP "Produto do Morro". Lado 1, Faixa 6, RCA Vik, 1983. 
bistas malandros" (Wilson Batista, Ismael Silva e Geraldo Pereira) presentes no cenário musical nas décadas de 1920 e 1930. O denominado "samba malandro", marcado pela ginga, se caracterizou pelo uso da cadência sincopada, apoiada na percussão, privilegiando temáticas do cotidiano e práticas "malandras" (recusa ao trabalho, predileção pelo ócio, boêmia, pequenos golpes, jogatina e cafetinagem). Com a repressão imposta pelo Estado Novo aos sambas da malandragem, as abordagens foram redefinidas, burlava-se a censura utilizando nas letras o duplo sentido, metáforas, humor e introduzindo o breque (declamado). Assim fizeram sambistas como Moreira da Silva, Jorge Veiga e Dicró, que foram inspiraçóes para Bezerra.

Embora identifique-se em Bezerra pontos em comum com esses "sambistas malandros", ele foi singular, não se enquadrando em nenhuma tendência específica, apesar de se apropriar de elementos do partido-alto e do samba de raiz, ele recriou temáticas tradicionais do samba (cotidiano dos morros, malandragem e religióes afro-brasileiras) ${ }^{5}$ e incorporou outras questóes (legalização da maconha, consumo de drogas, críticas à repressão policial, à corrupção e à desigualdade social).

Bezerra atuou como compositor no início da carreira, quando compunha cocos; com a mudança de gênero, suas composiçóes se tornaram esporádicas e, geralmente, feitas em parceria (das 270 faixas originais gravadas, ele assinou 20 sambas e em somente três foi o único autor). Na discografia de Bezerra percebe-se a presença dos compositores dos morros e subúrbios, ele percorria esses territórios em busca de novos talentos, estabelecendo uma extensa rede de autores que forneciam as cançôes (totalizando 254). Para além do lado profissional, cultivava relaçáo de amizade e convívio com esses compositores, buscando sempre valorizá-los.

Toda pessoa que procura ofuscar o valor do outro é porque não se garante (referia-se aos cantores que não dão oportunidades aos compositores) ... O disco depende de três matérias primas: o compositor, em primeiro lugar, depois o músico e, em terceiro plano, o cantor. Alguns colegas escondem isso. Dizem que não gravam a música porque o cara é ladrão, fuma maconha ou cheira pó, ou tem um sapato só... Aqui não tem jogo

5 Destacam-se na obra de Bezerra várias cançôes tematizando religiōes afro-brasileiras, principalmente a Umbanda, da qual foi praticante durante maior parte de sua vida; em várias ocasiôes o interprete assumiu sua fé e denunciou a intolerância religiosa. Apesar da presença das religióes afro-brasileiras nos morros, essas passaram por um declínio ante o crescimento das outras igrejas, processo vivenciado por Bezerra que se converteu ao neopentecostalismo, em 2002. Contudo, mesmo, após a conversão, o cantor continuou gravando e interpretando cançôes com o tema da Umbanda. Simultaneamente, ele planejou gravar um CD com cançôes voltadas para os evangélicos neopentecostais, "Caminho de Luz", que foi lançado após a sua morte em 2005 (Del Ré, 2003, p. 9; Marques, 2013, p. 41-42). 
rasteiro. Se digo que vou gravar uma música de um compositor, eu gravo... (Maria, 1987).

Nas interpretaçóes, Bezerra deixava sempre sua marca, realizava modificaçôes e adaptaçôes inserindo referências melódicas, temáticas e expressóes que visavam adequar a canção ao seu estilo. ${ }^{6}$ Ele era exigente e criterioso na seleção do repertório, priorizava a qualidade e originalidade nas composiçóes, manifestava clara preferência pelas temáticas que incorporavam denúncias das desigualdades e injustiças sociais. Apesar das críticas a essas escolhas, ele não aceitava a intromissão dos produtores ou das gravadoras.

\section{Bezerra da Silva: território - os morros}

Antes, aqueles morros não tinham nomes

Foi pra lá o elemento homem

Fazendo barraco, batuque e festinha

Nasceu Mangueira, Salgueiro, São Carlos e Cachoeirinha

Andaraí, Caixa d’Água, Congonha, Alemão e Boréu

Morro do Macaco em Vila Isabel

Matriz, Tuiti e Cruzeiro, Querosene, Urubu

Jacarezinho, Turano, Sossego e o Morro Azul

É mas no mesmo embalo nasceu Cantagalo, PavãoPavãozinho

O Morro da Guarda e Macedo Sobrinho

Tabajara, Providência, Santa Marta e Serrinha

Morro do Pinto, Sampaio, Dendê e a querida Rocinha

Ainda tem o Morro do Castro

6 Os compositores gravados por Bezerra eram moradores dos morros cariocas que na poética musical priorizavam as experiências cotidianas dessas comunidades. As interpretaçóes de Bezerra da Silva se caracterizavam por um estilo narrativo, uma opção pelo "canto falado", o que o aproxima do rap, sendo considerado um percursor desse gênero. $\mathrm{O}$ "canto falado" se posiciona numa zona tênue entre o canto e o entoar da letra, evidenciando, como nos depoimentos orais, "práticas culturais, estratégias de existência, costumes e temporalidades vividas pelos músicos e suas personagens ao estar e ser na cidade" (Azevedo, 2001. p. 400). 
E o Buraco do Boi como tem boa gente Atalaia, Martins, Morro do Oriente

Holofote e Papagaio, todos do outro lado

Areia Grossa, Cavaláo, São Lourenço e o Morro do Estado

É veja bem que nasceu também Sacopã, Catacumba e o Vidigal

Morro da Favela por trás da Central

$\mathrm{Eu}$ sou muito bem chegado neles não posso negar

Gosto de todos, mas o Cantagalo é que é meu lugar

(Aqueles Morros) $^{7}$

A proposta dessa composição era homenagear os morros, ${ }^{8}$ assim, os versos rememoram que inicialmente eles "não tinham nomes", nas primeiras ocupaçóes se fazia "barraco, batuque e festinha", depois foram criadas identidades e se difundiu o samba.

No início do século XX, as reformas urbano-higienistas do prefeito Francisco Pereira Passos, conhecidas como "bota-abaixo", levaram a destruição de cortiços no centro da cidade, selando o destino de seus moradores. Sem alternativas, essa população de despossuídos ocupou os morros e constituiu as favelas, construindo habitaçôes pequenas, frágeis e desordenadas, sem salubridade e infraestrutura (Benchimol, 1990; De Los Rios, 1991; Gonçalves, 2013; Abreu, 1994; Valladares, 2005; Campos, 2004).

O início efetivo dessas ocupaçóes e a origem do termo "favela" envolvem polêmicas. Para alguns, a origem do vocábulo (favela) encontra-se ligada a Guerra de Canudos (1896-1897) (Gonçalves, 2013, p. 44), pois existia naquela região um morro chamado Favela; os soldados participantes do conflito, ao retornarem, se estabeleceram no Morro da Providência, que, por similitude, foi denominado de "Morro da Favela".

Sobre o início efetivo das ocupaçôes, aponta-se que essa área já tinha moradores desde 1893 (Gonçalves, 2013, p.44), quando um dos proprietários do

7 Compositores: Pedro Butina e Bezerra da Silva. LP “Bezerra da Silva e um Punhado de Bambas". Lado 1, Faixa 1, RCA Victor, 1982.

8 Posteriormente gravaria outros dois sambas homenageando os morros: "Saudação às Favelas" (Pedro Butina, Sérgio Fernandes) no LP "Malandro Rife", Lado 1, Faixa 4, RCA Vik, 1983; "As Favelas que não exaltei” (Pedro Butina, Bezerra da Silva e Wilson Medeiros) no LP "Justiça Social”, Lado 2, Faixa 4, BMG-Ariola, 1987. 
famoso cortiço Cabeça de Porco alugou terrenos para alguns dos seus antigos inquilinos.

O termo "favela" se difundiu e passou a designar as ocupações espalhadas por outros morros da cidade, como o de Santo Antônio, Quinta do Caju, Mangueira e Serra Morena que também tiveram seu processo de ocupação nos finais do século XIX. Além disso, cabe observar que algumas favelas surgiram a partir de antigos quilombos que se encontravam disseminados na cidade e se tornaram alternativa de moradia para os ex-escravizados que ali chegavam (VAZ, 2002). Em síntese, no processo de ocupação dos morros, as ações e os grupos envolvidos foram variados, bem como, foram múltiplas as manifestações culturais e musicais presentes nesses territórios urbanos, merecendo destaque o samba.

As origens do samba também envolvem polêmicas, aponta-se que teria surgido no início do século XX (Caldas, 1985, p. 14-15) ainda em forma de ritmo, dança e folguedo coletivos (palmas, batuque, estribilhos cantados), aos quais foram acrescentados versos, alguns de autoria coletiva. Em áreas como a Saúde, Cidade Nova, Riachuelo e Lapa, a presença marcante de negros possibilitou a manutenção de suas tradiçóes e cultos; nesses territórios se promoviam encontros embalados por música e dança (bailes com sambas, batucada, gingado e sapateado), muitas vezes ocultados nos fundos das casas, como estratégia para evitar repressão policial (Matos, 1982, p. 25-26).

Nesse sentido, rememorou Donga, "o samba era considerado coisa de negros e desordeiros, andava muito perseguido" (Sodré, 1970). Da mesma forma, declarou o sambista João da Baiana:

O samba saiu da cidade. Nós fugíamos da polícia e íamos para os morros fazer samba. Não havia essas favelas todas. Existiam a Favela dos Meus Amores e o Morro de São Carlos, mais conhecido por Chácara do Céu. Nós sambávamos nesses dois morros [...] Mas o samba não nasceu no morro, nós é que levávamos, para fugir da polícia que nos perseguia (Matos, 1982, p. 28).

As favelas se constituíram enquanto comunidades, num processo de autoafirmação étnica e cultural, preservando manifestações musicais como o samba, em torno do qual se organizaram blocos, cordóes, clubes e as escolas. Cabe observar que nas décadas de 1950 e 1960, negros e mulatos representavam 95\% da população das favelas, que também contavam com a presença marcante de migrantes nordestinos (Gonçalves, 2013; Leeds; Leeds, 1978; Sousa, 2009).

Bezerra assumiu-se como porta-voz dessas comunidades e mediador cultural entre o morro e o asfalto. Em suas cançôes privilegiava as temáticas do cotidiano e vivências dos moradores das favelas, encontrando eco e constituindo um 
público.

O morro não tem voz, ele é somente atacado, mas não se defende. Como o morro não tem direito a defesa, só tem direito de ouvir "marginal", "malandro", "safado", acabou... Como é que ele vai falar? Então o que é que faz os autores do morro? Ele diz cantando aquilo que ele queria dizer falando, e eu sou o porta-voz. E é o pessoal do morro que escreve ou o pessoal da Baixada Fluminense... (Onde..., 2006).

O papel de porta-voz dos morros e favelas tornou-se evidente em várias cançôes, como em "Respeito às favelas":

Eu sou favela

Minha gente eu sou de lá

Não sinto vergonha e nem vejo motivos pra negar

Tudo que sei na vida aprendi com ela

Por isso eu tenho respeito tão grande por todas favelas

Só quem mora no morro é que pode dizer

O que é padecer e se sentir feliz

Vivendo e aprendendo a regra do conviver

Vendo a nossa semente ali criar raiz

Posso falar de cadeira, favela é meu berço, minha adoração

Será sempre exaltada nos versos que faço na minha canção

Favela, sei que você não é tão diferente assim

Não é esse lugar de gente tão ruim

Nunca foi ameaça pra sociedade cruel

Um dia você vai mudar em resposta dará sua volta por cima

E esse sistema terá que prestar contas a nossas colinas

(Respeito às favelas) $^{9}$

9 Compositores: G. Martins e Irani Gonçalves. CD "Malandro é Malandro e Mané é Mané". Faixa 7, Atração, 1999. 
Nessa canção, composta em primeira pessoa, o narrador (Bezerra) assume a condição de morador de favela - "Eu sou favela", e complementa que não sente vergonha e nem tem motivos para negar, considerando a favela o seu "berço". Diz que os residentes do morro sabem "o que é padecer e se sentir feliz", aponta as dificuldades enfrentadas e, ao mesmo tempo, destaca a alegria e a solidariedade presente nessas comunidades. Na sequência, assume um discurso defensivo, dizendo que, ao contrário do veiculado pela mídia e disseminado pelo senso comum, a favela não é "tão diferente assim", não é local de "gente táo ruim", "nunca foi ameaça pra sociedade", projeta que um dia a favela "dará sua volta por cima” e que se "terá que prestar contas" pela discriminação, preconceito e exclusão sofridas.

Nessa e em outras cançóes, Bezerra da Silva romantiza as vivências do morro como lócus de açóes de resistências aos valores culturais hegemônicos (Sodré, 1970); contudo, essa visão coexiste com as denúncias de dificuldades e carências cotidianas (infraestrutura, moradia, saúde, educação, segurança, saneamento, transportes), somando-se a ausência de políticas sociais capazes de amenizar essas situações.

As adversidades e carências dos moradores dos morros eram enfrentadas por meio de múltiplas estratégias, como a constituição de redes de solidariedade, sedimentadas em vínculos de parentesco, vizinhança, conterraneidade, associativos e religiosos. Através dessas redes circulavam informaçôes, viabilizava-se contatos e benefícios, criava-se laços afetivos (amizades, matrimônios, compadrio, entre outros) que contribuíam para fomentar a integração socioeconômica dos membros das comunidades, atenuando as condiçóes de vulnerabilidade.

Afora as redes engendradas, os moradores das favelas constituíram referências de identificação étnica e cultural manifestadas na institucionalização de açôes e organizaçôes. Como já apontado, o samba marcou as vivências das comunidades adquirindo importância, vinculando-se ao lúdico e ao lazer, possibilitando convívio e fuga de um cotidiano marcado pelas pressóes, opressóes, carências, desigualdades e discriminaçóes.

Desde a sua origem, as favelas foram associadas as "classes perigosas" (malandros, vagabundos, criminosos) e identificadas como ameaças à ordem social. Baseando-se nesses argumentos, se justificaram um conjunto de ações de combate e remoção das favelas durante os governos de Getúlio Vargas. Com a alegação de busca por melhorias nas favelas, foi criado o Código de Obras de 1937 (que vigorou até 1970) prevendo a extinção e remoção das habitaçóes consideradas como anti-higiênicas e perigosas. Conjuntamente, se propôs a construção de "parques proletários", conjuntos habitacionais populares destinados aos moradores dos morros. (Leeds; Leeds, 1978) Tais ações acompanharam o crescimento habitacional das favelas cariocas (de 170 mil para 335 mil habitantes entre a década de 1930 e 1960), mas os planos não seguiram adiante, entre outros motivos, devido 
as resistências da população que não aceitava se mudar para os conjuntos habitacionais, afastados do centro.

Em diferentes momentos dos governos militares, as políticas de remoção retornaram. A criação, em 1964, do Banco Nacional de Habitação (BNH), órgão responsável pelo financiamento e coordenação de programas habitacionais e, quatro anos depois, a institucionalização da Coordenação de Habitação de Interesse Social da Área Metropolitana (CHISAM), tinham como objetivo remover todas as favelas do Rio de Janeiro até 1976 (essa coordenação foi extinta em 1973, sem ter cumprido sua meta). Nesse processo, foram deslocados mais de 175 mil moradores de 62 favelas (remoção parcial ou total), transferidos para as 35.517 novas unidades habitacionais localizadas nas Zonas Norte e Oeste, sendo que a maior parte das remoçôes (cerca de 60\% dos barracos demolidos) se localizavam na Zona Sul. Houveram resistências capitaneadas por associaçóes de moradores de favelas e da Federação das Associaçóes de Favelas do Estado da Guanabara (FAFEG) (Brum, 2006; Perlman, 1977; Grabois, 1973).

Nas décadas de 1980 e 1990, acompanhando o processo de redemocratização, as remoçôes diminuíram, ocorrendo de forma esporádica. Na luta contra essas remoçôes, os moradores se organizaram através de várias instituiçóes (Pastoral de Favelas, associaçóes de moradores e ONGs), viabilizando a implantação de medidas de urbanização e melhoria dos morros. Com a criação, em 1992, do Plano Diretor do Município do Rio de Janeiro (exigência da Constituição de 1988), açôes de urbanização das favelas foram implementadas, porém, frente às pressóes sociais e interesses da especulação imobiliária, as propostas de remoção foram retomadas, agregando aos argumentos tradicionais (entre outros, o de riscos de deslizamentos), a violência urbana e o tráfico de drogas "oriundo das favelas" (Jacques, 2001; Brum, 2006)

Nesse contexto e visando denunciar a situação, Bezerra gravou o LP "Violência Gera Violência", com destaque para a seguinte canção:

Aí meu irmão

Quando eu cheguei da obra só tinha o lugar do barraco A chuva levou tudo malandragem

Quando o destino me pisa

O barraco desliza

Sou quase um defunto

E se escapo e não corro

Me expulsam do morro pra novo conjunto

Pego o trem de madrugada

Em cada parada não tem solução 
Meu verdadeiro endereço

É rua do avesso lá na construção

O operário brasileiro é mesmo agulha

Que costura e fica nua

Trabalha de janeiro a janeiro

Passa fome e mora na rua

Nem dá pra esquentar a cama

Atleta sem fama sou banda sem nome

Eu sou apenas mais um que não tenho nenhum

Meu salário é de fome

$\mathrm{O}$ trem me pega em Mesquita

E em cada marmita a comida só mingua

Já não tenho pro café

E só provo filé quando mastigo a língua

(Vida de operário) ${ }^{10}$

De forma irônica, o personagem/narrador descreve as dificuldades da população dos morros cariocas. Inicia apresentando o sofrimento pela perda da moradia (o barraco) num deslizamento, na sequência aponta a possibilidade da expulsão "pra outro conjunto", dando a entender que as remoções ocorriam de forma impositiva e sem a adesão dos moradores.

A canção também destaca as dificuldades cotidianas com o transporte público, as condiçóes precárias de vida e de trabalho, os baixos salários e a carestia vigente. Essas carências se mantiveram no período subsequente (anos 1990), marcado por crises, inflação, desemprego, acarretaram em empobrecimento, aumento das desigualdades sociais e precarização nos serviços públicos (saúde, educação, transporte, segurança, saneamento) (Caldeira, 2000; Almeida, 2009).

A insuficiência de programas de assistência governamental e a omissão do Estado levaram ao descrédito das instituiçóes oficiais, possibilitando a emergência de poderes paralelos nos morros cariocas. Bezerra da Silva, conhecedor da situação, apontou o controle, imposição de códigos de conduta (que regulavam comportamentos e formas de intimidação e violência) e todo o esquema de assistencialismo viabilizado pelo crime organizado.

Apesar da inexistência de um consenso sobre as origens do crime orga-

10 Compositores: Romildo, Ney Alberto e Edson Show. LP "Violência Gera Violência”, Lado 1, Faixa 3, BMG-Ariola, 1988. 
nizado, encontram-se indícios de articulaçóes com o jogo do bicho, quadrilhas especializadas em roubo a banco e a união de presos políticos com presos comuns durante os governos militares. Assim, se constituíram grupos organizados (facçôes) ${ }^{11}$ que se concentravam em açoóes como o tráfico de drogas, extorsōes e homicídios, passando a dominar as favelas exercendo uma espécie de poder paralelo de controle (Piccelli, 2013; Lesbaupin; Mineiro, 2002).

Essas experiências passaram a marcar o cotidiano dos morros e se fizeram presentes na obra de Bezerra, que foi acusado de ser "defensor de bandidos" e seus sambas-crônicas classificados como "sambandidos", rótulo, como já dito, que o artista rejeitava.

\section{Bezerra da Silva: malandragem e sambandido}

E malandro é malandro, Mané é Mané.

Podes crer que é

Malandro é malandro e Mané é Mané, diz aí!

Podes crer que é.

Malandro é o cara que sabe das coisas

Malandro é aquele que sabe o que quer

Malandro é o cara que tá com dinheiro

E não se compara com um Zé Mané

Malandro de fato é um cara maneiro

Que não se amarra em uma só mulher.

E malandro é malandro, Mané é Mané, diz pra mim.

Podes crer que é

Malandro é malandro e Mané é Mané, olha aí.

Podes crer que é.

Já o Mané ele tem sua meta

Não pode ver nada que ele cagueta

Mané é um homem que moral não tem

Vai pro samba, paquera e não ganha ninguém

Está sempre duro é um cara azarado

E também puxa o saco pra sobreviver

11 As principais organizaçôes criminosas conhecidas são: Comando Vermelho (CV), Primeiro Comando da Capital (PCC), Amigos dos Amigos (ADA), o Terceiro Comando (TC), o Terceiro Comando Puro (TCP) e a mais nova delas, as milícias. A maior parte se concentra no Rio de Janeiro, exceto o PCC, que surgiu nos presídios paulistas, mas se espalhou para outros estados. 


\section{Mané é um homem desconsiderado}

E da vida ele tem muito que aprender $[. .$.

(Malandro é malandro e mané é mané) ${ }^{12}$

Essa canção foi um dos maiores sucessos de Bezerra; a partir dela, ele buscou representar o "malandro de verdade", confrontando-o com o dito "mané". As antigas representaçóes do malandro (associadas a um tipo "original", cheio de ginga, malícia e astúcia) foram requalificadas na discografia do intérprete, na qual o termo "malandro" assumiu conotação polissêmica. Malandro podia designar criminosos e membros do crime organizado, políticos e líderes religiosos corruptos, porém, particularmente, também caracterizava o "verdadeiro malandro", que era o "cara maneiro", ardiloso (para sobreviver às dificuldades do dia a dia), capaz de enfrentar a violência, as injustiças, as desigualdades e os preconceitos, que estava inserido na sua comunidade, era solidário, considerado e reconhecido. Na narrativa, o intérprete esclarecia:

[...] o malandro é a pessoa inteligente, a palavra malandra quer dizer inteligência. E quando o camarada é rico, poderoso, ninguém vai dizer que ele é muito malandro, diz "Oh, o cidadão aí é o suprassumo da inteligência, é um grande homem”, assim como tem os grandes vultos né? E quando é pobre então não pode ser inteligente, então vira malandro, mas no sentido, querendo dizer que vive à margem da lei, que não sei mais o que, entendeu? Isso tudo são coisas de elite pra deturpar, entendeu? Porque isso aqui mesmo não tem malandro, ninguém aqui tem poder, ninguém tem imunidade, entendeu? Então, se você der uma volta em Brasília, aí você vai encontrar o malandro de verdade, faz o que bem quer, entende, fica por isso mesmo. Isso aí sim, agora aqui não, se nego roubar uma galinha entra em cana, não tem malandro, entendeu? Essa é a realidade. (Onde..., 2006).

Já o denominado "mané", era o que se considerava esperto, desprezava as normas de conduta, era desconsiderado e malvisto pela comunidade. Nos códigos de conduta, um tópico a ser respeitado era a não delação, estando o "cagueta"13 exposto a puniçóes (agressóes, assassinato e expulsão do morro).

12 Compositor: Neguinho da Beija-Flor. CD “Malandro é malandro e Mané é Mané”, Faixa 8, Atração, 1999.

13 A palavra cagueta é uma variação de alcaguete, que significa delator. (Michaelis, 2017). 
Visando evitar ações repressivas e violentas da polícia, as normas de conduta vigentes nos morros e favelas atuavam como forma de proteção de criminosos e dos demais moradores. Essas normas se somavam a outras práticas, como ocultar ou "malocar" 14 provas da polícia, evitando o flagrante de roubos ou tráfico de drogas. Através dessas táticas (Certeau, 1994), as comunidades dos morros resistiam à dominação imposta.

Bezerra reinterpretou a malandragem, atualizando-a aos novos contextos, incorporando ao seu "canto falado" as formas de expressão e gírias que circulavam nos morros. Existiam gírias comuns a várias comunidades, porém, algumas eram restritas a certos territórios ou facçôes, como um código próprio que apenas aqueles inseridos no grupo podiam acessar e entender. Como mediador cultural ${ }^{15}$ Bezerra se atualizava das mudanças e se apropriava de símbolos, gírias e práticas, facilitado pela sua inserção e conexốes com os moradores dos morros.

O termo "sambandido" surgiu no final da década de 1980, momento em que a violência urbana se expandiu e a temática se tornou mais frequente no samba. O termo nem sempre foi usado de forma pejorativa, sendo identificado como algo diferente do produzido até então, tendo como constância os assuntos relacionados à criminalidade. Bezerra declarava que o gênero musical que produzia era o partido-alto e se opunha à utilização do rótulo de "sambandido", que, segundo ele era "coisas de mídia" (Vianna, 1999).

O que eu faço é Partido Alto. O resto é invenção da mídia. Esse negócio que eu sou cantor de bandidos... Eu sou cantor popular. Se querem chamar o povo de bandido, bem, aí o negócio é outro...

Então, como eles dizem a realidade, que dói, então eles aí dizem que eu sou cantor de bandido, porque os autores que escrevem para mim são favelados, são não sei o que [...] Bezerra é cantor de bandido, idolatrando marginal, é do lado, é defensor de bandido, eu digo, bicho, quem defende bandido é advogado, juiz, né? (Onde..., 2006).

Bezerra considerava depreciativa a alcunha "cantor de bandidos", recebida por interpretar cançóes com temas incômodos como exploração e desigualdade

14 Nessa prática, os criminosos escondem ou se desfazem das provas de crimes (roubos, furtos ou drogas) para não se enquadrar em crimes flagrantes, diminuir as provas, reduzindo ou anulando o risco de condenaçóes pesadas e prisôes.

15 Ao incorporar em suas canções expressões, gírias e visões de mundo que circulavam nos morros e subúrbios cariocas, Bezerra atuava como uma espécie de mediador cultural, lembrando que seus discos batiam recordes de venda e eram consumidos por sujeitos históricos de diversas classes sociais. 
social, denunciando procedimentos coercitivos, como o uso da violência na repressão policial. A identificação de Bezerra como "cantor de bandidos" também esteve relacionada à sua aproximação com José Carlos dos Reis Encina (conhecido como "Escadinha"), um dos fundadores e principais líderes do Comando Vermelho $(\mathrm{CV})$. Ele gravou duas cançóes ("Justiça Social" 16 e "O Juramento é o meu lugar"17) referenciando Escadinha e citando a popularidade que possuía no Morro do Juramento. Isso se somava aos seus contatos com os presidiários, a gravação de cançôes que falavam do cotidiano no sistema prisional ("Ilha Grande", 18 "Bangú I", ${ }^{19}$ "Filho de Mãe Solteira", ${ }^{20}$ "Malandro não cagueta", ${ }^{21}$ "SOS Baixada"22 e "Bicho Feroz"23), além disso, realizava shows beneficentes em presídios do Rio de Janeiro.

Bezerra: [...] Porque aqui no Rio só canto em favela ou então em presídio. O Estado de S. Paulo: Em presídio?

Bezerra: É, já cantei em todos os presídios do Rio, menos em Bangu I (presídio de segurança máxima) e Água Santa, que são considerados castigo para os presos e não podem receber artistas. Mas nos outros cantei, até no feminino. Sou campeão nisso.

O Estado de S. Paulo: E eles pagam?

Bezerra: Não pagam porque é o diretor que convida, manda ofício... Eu faço de graça. Sempre em Dia das Mães, Natal, essas coisas. (Migliaccio, 1996).

Bezerra não saiu ileso à censura, alguns sucessos como "Malandragem dá um tempo"24 e "São Murungar" 25 foram barrados pelos órgãos repressores:

16 Compositores: Marujo e Duda. LP “Justiça Social”. Lado 1, Faixa 6, BMG-Ariola, 1987.

17 Compositores: Eliezer da Ponte e Gil de Carvalho. CD "Eu tô de pé”. Faixa 8, Universal Music, 1998. 18 Compositor: J. Laureano. LP “Justiça Social”. Lado 2, Faixa 2, BMG-Ariola, 1987.

19 Compositor: Raimundo de Barros Filho, Jorge Teixeira, Eli Santos e Zé do Galo. CD "Meu samba é duro na queda”, Faixa 10, RGE, 1996.

20 Compositores: Sassarico e Bicalho. LP "Violência gera violência”. Lado 2, Faixa 6, BMG-Ariola, 1988.

21 Compositores: Julinho Belmiro e Jorge Garcia. LP "Se não fosse o samba”. Lado 1, Faixa 4, BMG-Ariola, 1989.

22 Compositores: Nilson Reza Forte e Bimba do Tavares Bastos. LP "Presidente Caô Caô". Lado 1, Faixa 3, BMG-Ariola, 1992.

23 Compositores: Tonho e Cláudio Inspiração. LP “Malandro Rife”. Lado 1, Faixa 1, RCA Vik, 1985.

24 Compositores: Popular P, Adelzonilton e Moacir Bombeiro. LP "Alô malandragem, maloca o flagrante". Lado 1, Faixa 1, RCA, 1986.

25 Compositor: Jayminho. LP “Justiça social”. Lado 1, Faixa 3, BMG-Ariola, 1987. 
O Estado de S. Paulo: E de censura, você entende?

Bezerra: Também não. As músicas que eu gravo são o dia-a-dia, a pura realidade. Se tem gente que não gosta de ouvir, é outro papo. O que tem demais em cantar "Me diz vovó, quem foi que botou maisena no meu pó?” (letra de São Murungar, censurada em rádio e televisão). O duplo sentido quem faz é a própria censura. E os intelectuais. Do jeito que eles censuram é caô-caô. (Stycer, 1987).

No repertório de Bezerra, as cançóes que receberam maior questionamento e censura foram as relacionadas à temática do uso e comercialização de drogas. Embora, declarasse não ser usuário de drogas, ele defendia a legalização da maconha, envolvendo-se em calorosos debates. Nesse contexto, se inserem cançóes como "Garrafada do Norte", 26 "Deixa uma paia pro véio queimá", ${ }^{27}$ "Já nasci com cabeça", 28 "Malandragem dá um tempo", ${ }^{29}$ "A semente", 30 "Grampeado com muita moral", ${ }_{11}$ "A fumaça já subiu pra cuca"32 e "Se Leonardo dá vinte... ". 33

$\mathrm{Na}$ narrativa, o intérprete apontava que o motivo principal da perseguição à sua obra era o caráter crítico e de denúncia:

Eu canto o cotidiano, o dia a dia, a pura realidade. E o povo do morro diz cantando aquilo que não pode dizer falando [...] Não se conforma. "Vou Apertar", diz, já não foi bem compreendido, pois "era um alerta sobre o uso de drogas, mostrava o que pode acontecer quando se acende um cigarro de maconha”. (Mendes, 1987).

Bezerra associava as críticas sobre sua obra ao preconceito social vivenciado pelo seu público oriundo dos morros, favelas e subúrbios. Mais que do que

26 Compositores: Edson Show, Wilsinho Saravá e Roxinho. LP "Presidente Caô Caô", Lado 2, Faixa 4, BMG-Ariola, 1992.

27 Compositor: Adelzonilton. LP “Bezerra e um Punhado de Bambas”, Lado 1, Faixa 4, RCA Vik, 1982.

28 Compositores: Naninha, Oswaldo Hugo e Almir Ribeiro. LP “Malandro Rife”, Lado 2, Faixa 4, RCA Vik, 1985.

29 Compositores: Popular P, Adelzonilton e Moacyr Bombeiro. LP "Alô Malandragem Maloca o Flagrante", Lado 1, Faixa 1, RCA Vik, 1986.

30 Compositores: Walmir da Purificação, Tião Miranda, Roxinho e Felipão. LP “Justiça Social”, Lado 2, Faixa 3, BMG-Ariola, 1987.

31 Compositores: Adelzonilton, Carnaval e Moacir da Silva. LP "Presidente Caô Caô", Lado 1, Faixa 5, BMG-Ariola, 1992.

32 Compositores: Adelzonilton e Tadeu do Cavaco. LP "Meu samba é duro na queda”, Lado 1, Faixa 2, RGE, 1996.

33 Compositores: G. Martins, Walter Coragem e Bezerra da Silva. CD “Bezerra da Silva ao vivo”, Faixa 18, CID, 2000. 
isso, entendia-se perseguido por se assumir como defensor dos setores populares da sociedade brasileira:

Em defesa de todas as favelas do meu Brasil

Aqui fala o seu embaixador

Sim, mas a favela nunca foi reduto de marginal

A favela nunca foi reduto de marginal

Só tem gente humilde marginalizada

E essa verdade não sai no jornal

A favela é um problema social

É, mas eu sou favela

E posso falar de cadeira

Minha gente é trabalhadeira

E nunca teve assistência social

Sim, mas só vive lá

Porque para o pobre não tem outro jeito

Apenas só tem o direito

A um salário de fome e uma vida normal

$(\text { Eu sou favela })^{34}$

Nessa canção, observa-se que Bezerra assumiu a persona artística de "embaixador do samba e dos moradores dos morros". Num sentido político, afirma que "a favela nunca foi reduto de marginal" e que seus habitantes são pessoas "humildes marginalizadas", trabalhadores que enfrentam o cotidiano árduo, encaram os preconceitos e a carência de assistência social.

Os moradores dos morros e favelas não aceitam passivamente o preconceito, violência, agressóes e injustiças que lhes são impostas, resistem através de táticas, aperfeiçoam habilidades para evitar enfrentamentos diretos, constituem articulações internas, constroem estratégias contra os abusos e sem resignação se mantêm esperançosos, combativos na manutenção de sua singularidade e cultura. A própria a obra de Bezerra pode ser identificada como uma forma de resistência cultural, pelas temáticas incorporadas: denúncia da situação de desigualdade, exclusão, repressão e violência, representaçôes das resistências e práticas cotidianas

34 Compositores: Noca da Portela e Sergio Mosca. LP "Presidente Caô Caô", Lado 1, Faixa 2, BMG-Ariola, 1992. 
vigentes nesses territórios (malandragem e códigos de conduta). Porém, ao focalizar esses temas, Bezerra e sua obra foram estigmatizados e, apesar da significativa venda de discos, sucesso em shows e repercussão midiática, o artista teve seu trabalho desqualificado e criticado pela imprensa especializada.

\section{Conclusão}

No século XXI, os morros cariocas passaram por mudanças e interferências, incluindo novas açôes de urbanização, tentativas de pacificação com a instalação das Unidades de Polícia Pacificadora (UPPs) e a presença do exército. Apesar da manutenção das tensóes e violências cotidianas, observa-se tentativas de transformaçôes nas dinâmicas internas, a busca por atribuição de novas funçôes e a luta pelo reconhecimento das particularidades culturais das favelas (Mendes, 2014).

Nesse contexto, mesmo que tardio, emerge o reconhecimento da obra e da trajetória de Bezerra da Silva por parte da mídia, críticos e intelectuais, alterando seu status de marginal para cult e possibilitando a sua incorporação (com regravaçóes e reinterpretaçóes) em produçóes nacionais e internacionais. Isso pôde ser verificado, entre outros, no lançamento em escala mundial do jogo on-line para computadores Counter Strike, tendo como cenário o Morro Dona Marta (o mesmo onde décadas antes Michael Jackson gravara um de seus clipes) e como fundo musical uma canção interpretada por Bezerra (Erthal, 2002).

\section{Referências}

ABREU, Mauricio de Almeida. Reconstruindo uma história esquecida: origem e expansão inicial das favelas do Rio de Janeiro. Espaço \& Debates, São Paulo, v. 14, n. 37, p. 34-46, 1994.

A CARA do Rio. Direção de Eloy Deiró. Apresentação de Jair Marchesini. Programa de TV. Rio de Janeiro: TVJM, 21 nov. 2000.

ALCAGUETAR. In: MICHAELIS. Alcaguetar. São Paulo: Melhoramentos, 2017. Disponível em: <http://michaelis.uol.com.br/busca?palavra=alcaguetar\&r=0\&$\mathrm{f}=0 \& \mathrm{t}=0>$. Acesso em: 15 mar. 2017.

ALMEIDA, Manoel Donato de. Neoliberalismo, privatização e desemprego no Brasil (1980 - 1998). Tese (Doutorado em Ciências Sociais) - UNICAMP, Campinas, 
SP, 2009.

AZEVEDO, Amailton Magno. No ritmo do rap: música, oralidade e sociabilidade dos rappers. Projeto História, São Paulo, v. 22, p. 357-376, jun. 2001.

BENCHIMOL, Jaime Larry. Pereira Passos: um Haussmann tropical. Rio de Janeiro: SMCTT, 1990.

BRUM, Mário Sergio Ignácio. O povo acredita na gente: rupturas e continuidades no movimento comunitário das favelas cariocas nas décadas de 1980 e 1990. Dissertação (Mestrado em História Social) - UFF, Niterói, RJ, 2006.

CALDAS, Waldenyr. Iniciação à música popular brasileira. São Paulo: Ática, 1985.

CALDEIRA, Teresa Pires do Rio. Cidade de muros: crime, segregação e cidadania em São Paulo. São Paulo: Edusp, 2000.

CAMPOS, Andrelino. Do quilombo à favela: a produção do "espaço criminalizado" no Rio de Janeiro. Rio de Janeiro: Bertrand Brasil, 2004.

CERTEAU, Michel de. A Invenção do Cotidiano: 1 - Artes de fazer. Petrópolis: Vozes, 1994.

DE LOS RIOS, Adolfo Morales. Dois Notáveis Engenheiros: Pereira Passos e Vieira Souto. Rio de Janeiro: Editora A Noite,1991.

DEL RÉ, Adriana. Bezerra da Silva, o malandro evangélico. O Estado de São Paulo. Caderno 2. São Paulo, p. 9, 21 ago. 2003.

ERTHAL, João Marcello. Computador simula guerra do tráfico: adolescentes se reúnem para trocar tiros, pela internet, com traficantes e policiais virtuais no Morro Dona Marta. Jornal do Brasil. Caderno Cidade. Rio de Janeiro, p. 4.10 mar. 2002.

GONÇALVES, Rafael Soares. Favelas do Rio de Janeiro: História e Direito. Rio de Janeiro: Pallas, 2013.

GRABOIS, Gisélia Potengy. Em busca da integração: a política de remoção de favelas no Rio de Janeiro. Dissertaçấo (Mestrado em Planejamento Urbano), - UFRJ, Rio de Janeiro, RJ, 1973. 
JACQUES, Paola Berenstein. Estética das favelas. Arquitextos. São Paulo, n. 13, 2001. Disponível em: <http://www.vitruvius.com.br/arquitextos/arq000/esp078. asp>. Acesso em: 1 jan. 2017.

LEEDS, Anthony; LEEDS, Elizabeth. A Sociologia do Brasil urbano. Rio de Janeiro: Zahar, 1978.

LESBAUPIN, Ivo; MINEIRO, Adhemar. O desmonte da nação em dados. Petrópolis: Vozes, 2002.

MARQUES, Vagner Aparecido. O irmão que virou irmão: rupturas e permanências na conversão de membros do PCC ao pentecostalismo na Vila Leste - SP. Dissertação (Mestrado em Ciências da Religião) - PUC, São Paulo, SP, 2013.

MATOS, Claudia. Acertei no milhar: malandragem e samba no tempo de Getúlio. Rio de Janeiro: Paz e Terra, 1982.

MATOS, Maria Izilda Santos de. Corpos e emoçôes: história, gênero e sensibilidades. São Paulo: e-Manuscrito, 2018.

MARIA, Cleusa. O mocotó do Samba: Em torno de um suculento prato, Bezerra da Silva reúne compositores. Jornal do Brasil. Caderno B. Rio de Janeiro, p. 2, 8 jan. 1987.

MENDES, Antônio José. Tem maisena nesse pó: Bezerra da Silva lança disco e briga de novo com a censura. Jornal do Brasil. Caderno Perfil. Rio de Janeiro, p. 12-13, 31 mai. 1987.

MENDES, Izabel Cristina Reis. O uso contemporâneo da favela na cidade do Rio de Janeiro. Tese (Doutorado em Arquitetura e Urbanismo) - USP, São Paulo, SP, 2014.

MIGLIACCIO, Marcelo. Bezerra da Silva chega à Zona Sul Carioca. O Estado de São Paulo. Caderno 4. São Paulo, p. 2, 15 jul. 1996.

MORRE aos 77 anos o compositor Bezerra da Silva. Revista Época. Quem News. São Paulo, 17 jan. 2005.

ONDE a Coruja Dorme. Direção de Márcia Derraik e Simplício Neto. Docu- 
mentário, 72 min. Rio de Janeiro: Antenna Arte e Ciência; TV Zero, 2006.

PERLMAN, Janice. O mito da marginalidade: favelas e política no Rio de Janeiro: Paz e Terra, 1977.

PICCELLI, Aline Maria. Neoliberalismo, crime organizado e milícia nos morros cariocas nos anos 1990 e 2000. Dissertação (Mestrado em Ciências Sociais) - UEL, Londrina, PR, 2013.

PORTELLI, Alessandro. A filosofia e os fatos: narração, interpretação e significado nas memórias e nas fontes orais. Revista Tempo, Rio de Janeiro, v. 1, n. 2, p. 59-72, 1996.

SANTHIAGO, Ricardo. História Oral e as artes: percursos, possibilidades e desafios. História Oral, v. 16, n. 1, p. 157-169, jan./jun. 2013.

SODRÉ, Muniz. Samba, o Dono do corpo. Rio de Janeiro: Codecri, 1970.

SOUSA, Rainer Gonçalves. Bezerra da Silva e o cenário musical de sua época: entre as tradiçóes do samba e a indústria cultural (1970-2005). Dissertação (Mestrado em História) - UFG, Goiânia GO, 2009.

SOUZA, Tárik. Conversa de bambas: o confronto de malandros. Jornal do Brasil. Caderno B. Rio de Janeiro, p. 2, 23 abr. 1986.

STYCER, Mauricio. Bezerrão. O Estado de São Paulo. Caderno 2. São Paulo, p. 6, 26 jul. 1987.

VALLADARES, Lícia do Prado. A invenção da favela: do mito de origem a favela. com. Rio de Janeiro: FGV, 2005.

VAZ, Lílian Fessler. Modernidade e moradia: habitação coletiva no Rio de Janeiro, séculos XIX e XX. Rio de Janeiro: 7Letras, 2002.

VIANNA, Letícia Costa Rodrigues. Bezerra da Silva, produto do morro: Trajetória e obra de um sambista que não é santo. Rio de Janeiro: Jorge Zahar, 1999.

Resumo: Estes escritos discutem questôes referentes a experiências urbanas vivenciadas nos morros cariocas tendo como base metodológica a História Oral 
(entrevistas elaboradas por outros pesquisadores e pelos autores), história e música (oralidade da poética das cançóes). Tal proposta prioriza a trajetória e a obra de Bezerra da Silva. O artista privilegiou no seu repertório questóes presentes no cotidiano dos moradores dos morros, com destaque para temáticas como violência, carência, desigualdade, drogas, criminalidade, malandragem, entre outras.

Palavras-chave: Bezerra da Silva. Cidade. Morro. Oralidade, Música. Malandragem.

\title{
Urban experiences and tensions: paths, orality and music on Bezerra da Silva
}

\begin{abstract}
These writings discuss issues related to urban experiences lived in the hills of Rio de Janeiro based on the methodological oral history (interviews prepared by other researchers and the authors) and history and music (orality of the poetics of the songs). It is aimed to privilege Bezerra da Silva's path and work. The artist favored, in his repertoire, issues from the daily lives of the hills' residents, with emphasis on themes such as violence, shortage, inequality, drugs, criminality, trickery, among others.
\end{abstract}

Keywords: Bezerra da Silva. City. Hills. Orality, Music. Trickery.

Recebido em 02/08/19

Aprovado em 05/11/19 